\title{
The Public Perception of Corporate Social Responsibility and Its Effects on Customer Behaviour in China
}

\author{
Junwu Chai, Pengfei Chang, Zhenhua Wang, Yaw Brew \\ School of Management and Economics, University of Electronic Science and Technology of China, Chengdu, \\ China \\ Email: chaijw@uestc.edu.cn, cpffrank@163.com
}

Received 15 September 2015; accepted 24 October 2015; published 27 October 2015

Copyright (C) 2015 by authors and Scientific Research Publishing Inc.

This work is licensed under the Creative Commons Attribution International License (CC BY). http://creativecommons.org/licenses/by/4.0/

(c) (i) Open Access

\begin{abstract}
With the rapid economic development of China, many enterprises have developed rapidly with the growing scale and strength, and their products and services have had a profound impact on the society. However, the study finds that many enterprises are merely spectators toward corporate social responsibility (CSR); these enterprises do not play an active role in CSR. At present, the domestic and foreign scholars' researches on CSR are focused on motivation, influence factors and its influence on enterprise performance, but less attention has been given to the public perception of CSR and its different effects on customer behavior from the demographic range. This paper is based on a questionnaire of public perception in CSR, advancing with the times to consider the current status of the public's perception of CSR in China, at the same time, it investigates the public's attention to the dimensions of CSR at present, and particularly analyzes the perception of CSR and its different effects on customer behaviour in the demographic indicators.
\end{abstract}

\section{Keywords}

Corporate Social Responsibility, Perception, Stakeholder, Customer Behaviour

\section{Introduction}

A large number of enterprises have emerged because of Chinese rapid economic development. Their scale and social status increase day by day, however, in contrast, the social responsibility performances of some enterprises are not positive. According to statistics, serious deficiency of CSR becomes a commonsense among stateowned enterprises, private enterprises and foreign-invested enterprises. Nearly $70 \%$ enterprises are spectators in 
terms of corporate social responsibility [1]. In recent years, the emergence of social responsibility awareness results in the changes of consumers' ways of thinking. Consumers focus more on the enterprise execution of social responsibility and regard CSR as the reference index of purchasing. Therefore, under this circumstance, the enterprise will be "punished" by consumers if they only pursue the economic benefits but ignore the CSR, also the enterprise performance [2] and its capital market will be affected [3].

The undertaking of the CSR turns into an international development trend. The enterprise must surpass the traditional products and market view and focus on the humanistic spirit, social responsibility and value pursuit of the new era [4]. Under the background of current economic upheaval, frequent climate changes, environmental disasters and social media emergence, it's a theoretic and practical project to discuss CSR. This article will study the CSR perception status of Chinese citizens and the impact of this perception on the consumer behavior. At the meantime, this article will discuss the influence of demography on this perception in detail, in the hope that this article will inspire more enterprises to shoulder concern and think deeply about social responsibility.

\section{Theoretical Background}

\subsection{Public Perception of CSR}

Corporate Social Responsibility (abbreviated as CSR) refers to the obligation of protecting and improving the public interest that the corporate shall undertake while pursuing legal economic interest [5]. In the 1920s, a British scholar proposed the conception of CSR, but there is no agreed definition till now. Carroll (1998) found over 25 types of CSR definition according to the statistics of relevant records [6], and he proposed a classic pyramid model, namely, CSR refers to the expectations of society on the economy, laws, ethnics and free decision (charity), and including economic responsibility, legal liability, ethical responsibility and philanthropy responsibility $[7]$.

As for the public perception of CSR, Webster (1975) found that a certain type of consumers would take the public influence of corporate into consideration for private consumption; they would like to purchase the products of the enterprises which possess positive influence on the society, and in this way to promote the better development of society. This type of consumers is defined as the consumers with social responsibility conscientiousness [8]. After this, scholars have conducted deeper researches on this type of consumers, such as their psychological features, behavior characteristics and the proportion in the society. On the basis of former scholars, Roberts (1995) developed the classic measurement scale of public consciousness on social responsibility and conducted a mass investigation and statistical analysis on the American consumers with social responsibility consciousness [9].

Morh and other scholars' (2001) conducted further investigation on the basis of Webster. The study shows that, a type of consumers tends to purchase the products of the enterprises which possess positive contribution to the society for the sake of moral aspect. They defined this type of behavior as customer behaviors with social responsibility and this behavior varied with the demographic characteristic [10]. Sen and other scholars (2001) proposed the conception of corporate social responsibility support at the same time, namely, the consumers support the corporation with good reputation of CSR performance, and set this CSR support as an important regulated variable for the CSR influence on the consumer purchase behavior [11]. Later, Morh and other scholars (2005) also found that the purchase intention of consumers was affected by the CSR support degree of the enterprise. The higher CSR support degree and more sensitive perception of CSR lead to stronger purchase intention of consumers [12].

\subsection{Research of CSR Dimensions}

Domestic and international scholars hold different views on the CSR dimensions. Scholar Munilla (2004) summarizedseven (7) parts of CSR, namely, the responsibility for shareholders and creditors, the responsibility for employees, the responsibility for government, the responsibility for collaborator, the responsibility for consumers, the responsibility for community and the responsibility for environment [13]. Xu Shangkun (2010), summarized nine (9) dimensions of Chinese CSR conceptual category by survey and analysis, and these dimensions all reflect a certain expectation of the public to the enterprises under current social background [14]. In addition, quite a few scholars and relevant researchers believe that CSR is divided into three (3) dimensions. Committee for Economic Development compares the CSR as a concentric circle, which owns three layers from within. The first layer is the most basic economic responsibility of the corporation; it includes the basic responsibility of 
providing qualified products, employment and economic growth; the second layer is the active response towards social values, including maintaining the relationship between enterprise and employees, and proper handling of environmental issues etc.; the third layer is an open state and will continuously update with social development [15]. Chen Xun and other scholars (2005) believe that CSR includes three (3) layers. The basic layer: responsible for shareholders and benice to employees; the middle layer: responsible for consumers, comply with the government policies, good community relationship and environment protection; the higher layer: charitable donation and make earnest efforts to promote public good [16]. In spite of different divisions of CSR dimensions because of different research views, the scope of CSR is basically confirmed.

Besides, some scholars and institutions conduct surveys on the public concerned CSR dimensions. AmarketConsultation Company and Sohu Finance made an investigation in 2006. The survey content included the public understanding of CSR, the public assessment of Chinese current CSR status and public attention of each CSR dimension etc. Results showed that, the interviewees think that the most needed social responsibilities for Chinese enterprises are, product safety, environmental protection, public safety, paying tax and public welfare programs [17]. JinBei (2006) and other scholars made a survey on the CSR connotation from another dimension. Results showed that, the environmental expenditure of production, labor social security investment and tax amount were the main elements of CSR. The above aspects measure the social responsibility of corporate from the perspective of society, employee and government [18]. In 2008, a survey from CSR Research Center of Chinese Academy of Social Sciences Economic Research Department showed that, the public concerned parts of CSR respectively were: paying taxes according to law (57.0\%), ensure product quality (51.6\%), energy conservation and environmental protection (47.2\%) and ensure employee interest (46.7\%) [19]. Scholar Xu Shangkun found that the three dimensions, namely, staff development and rights, environmental protection and legal liability, earned the highest public attention [14]. In the end of 2001, China Youth News also conducted a survey on the CSR dimensions from a public perspective, and the most concerned three dimensions were the employee welfare and salaries, non-aggression of consumer rights and complying with commercial morality (Table 1).

\subsection{Influence Study of CSR on Public Consuming Behavior}

Although many divergences exist among the domestic and international CSR researches, the surveys of CSR behaviors and consumers' attitude toward enterprise and its product and service are somehow accordant. Earlier in 1975, Webster proposed the conception of "Social Responsibility Consciousness Consumer" and defined the behavior of this type of consumer as "Social Responsibility Consumer Behavior" because they would consider the public influence caused by personal consuming behavior or try to change the world by his/her purchasing behavior when purchasing. This type of consumers would also "try to minimize or eliminate the detrimental effect on society and maximize the social long-term interests by means of personal obtainment, usage and handling of products” [8].

The reciprocity theory believes that consumers will praise virtues on the enterprises, namely, show their positive attitude towards the enterprises that are willing to take CSR responsibility; in opposite, the consumers will punish the enterprises that avoid or harm CSR, namely, show their negative attitude [20]. Corporate performance of social responsibility may form the lever effect by affecting consumers' perception, thus to obtain the differential competitive advantage [21]. The favorable social responsibility behavior positively affects the cus-

Table 1. Conclusion of public attention for CSR dimensions.

\begin{tabular}{|c|c|c|}
\hline Year & Source & The most concerned items of CSR dimensions \\
\hline \multirow[t]{2}{*}{2006} & Consulting Company Sohu Finance & $\begin{array}{l}\text { Product safety, environmental protection, } \\
\text { public safety, paying tax and public welfare programs }\end{array}$ \\
\hline & JinBei etc. & $\begin{array}{l}\text { Environmental expenditure for production, } \\
\text { labor social security investment and tax amount }\end{array}$ \\
\hline 2008 & Chen Jiagui etc. & $\begin{array}{c}\text { Paying tax, product quality, environmental protection } \\
\text { and guarantee staff benefits }\end{array}$ \\
\hline 2010 & Xu Shangkun & $\begin{array}{l}\text { Staff development and rights, environmental protection } \\
\text { legal liability (pay taxes and lawful operation) }\end{array}$ \\
\hline 2011 & China Youth News & $\begin{array}{l}\text { Staff welfares and salaries, non-aggression of consumers' } \\
\text { rights and complying with commercial morality }\end{array}$ \\
\hline
\end{tabular}


tomers' assessment on the products and services [22], and indirectly influences the consuming behavior of consumers by the intermediate variables, such as brand image etc. [23]. Sen and other scholars (2001) proved that the fulfillment level of CSR will directly affect the consuming behavior of consumers [11]. This shows that the company behavior of CSR not only affects the customer assessment, but also affects the consuming behavior of consumers. Consumers with social responsibility consciousness would be more willing to purchase the products from the enterprises, which contribute positive impact on the society. At the same time, the consumers avoid purchasing products from the enterprises which behave unethically or cause social damages [24].

Although many domestic and international researches have been conducted on CSR, they mainly focus on the behavioral motive, influence factor and corporate CSR performance. The complete concept and evaluation system have not been formed yet; and in sufficient researches have conducted on the CSR dimensions. This article studies the public perception of CSR in China and the most concerned CSR dimensions based on the investigation of public perception of CSR. Although similar researches have been made by domestic scholars before, the results vary a lot from both horizontal and vertical perspective according to our statistics. CSR relies on the certain period and background and its dimensions and public perception keep pace with time. This article investigates the public perception of CSR in the new era, and specially analyzes the above mentioned perceptions and influences of consumers' consuming behavior on the difference of demographics index; furthermore, this article also provides the empirical analysis from the perspective of CSR dimensions, also the influence of CSR on the purchasing selection attitude of consumers.

\section{Research Suppositions and Data Collection}

\subsection{Research Suppositions}

The research content of this article mainly contains a series of actual questions that the public cares more, such as, what kind of social responsibility the corporate should undertake, the implementation status of CSR, the effect on the consumer purchasing selection. At present, there are no agreed CSR dimensions. The domestic and overseas scholar study the CSR dimensions from different perspectives, while the dimensions used in this article are from the consumers' perspective mainly includes the following eight CSR dimensions: paying tax, product safety, after-sales service, employee welfare, responsibility for other manufacturers, environmental protection, bring benefits to local residents, promote the economic development and public welfare programs.

This article studies the influence of CSR on the consuming behavior of consumers. It mainly focuses on the difference of this influence on the demographics, and also conducts deep analysis on the differentiation of reaction degree toward this perception, and then finds the groups which are sensitive to CSR. In the meantime, analyze the consuming attitudes of different groups, including purchase intention, acceptance level of premium, and approval degree of product under the condition of the enterprise with favorable CSR performance.

The questionnaire for the study had three parts, namely, filter questions, background questions, and demographics. The first part is filter questions, which are capable of directly filtering the unqualified investigators and improving reliability and validity of the survey results; the second part is divided into two sections, the first section aimed to investigate the public perception status of CSR. This section investigates the public perception status and concern degree by designing ten questions. Section two was designed to investigate the influence of CSR on the consumers. This section investigates the influence of CSR on the consumer selection by adopting the questionnaire method, the questions of this section can well reflect the public perception status of CSR, and the influence degree of CSR difference on the consumers' selection; the third part is demographics survey, mainly to investigate the gender, education background, occupation, income and current city of the respondents.

\subsection{Data Collection}

The data collection of this article was completed by Beijing Zero Advertisement Company. Multi-stage random sampling was adopted for sampling based on the procedure of neighborhood committee totality-sampling neighborhood committee-sampling household-individual. This article selects some representative cities according to geographic orientation and economic development degree, including Beijing, Shanghai, Guangzhou, Wuhan, Xi'an, Chengdu and Shenyang. This survey limits the age of research objects between 16 years old to 60 years old urban consuming group with self-care ability and normal understanding ability. The method of the sampling family selection is selecting one family every five families. The samples of one committee are not 
more than 10 families, and the committee number of every region cannot be less than $10 \%$ of the total samples. If the drawn sampling family, which is based on the above sampling method, is not at home, the interviewer shall knock the door every 2 hours at 3 different time period, if this family is still not at home, visit the next sampling family for replacement. If one or more qualified objects appear in the family, decide the only target interviewee in the sampling family based on KISH sampling method. This survey adopts resident face-to-face interview, which adopts the method of interviewer reading and recording, namely, the interviewees answer the questions, and the interviewer fills in the questionnaire, and then sends the interviewee a souvenir after interview. Lastly, the researchers checked the interview by telephone calls according to the $20 \%$ compound proportion of every city. At last, there were 1093 effective samples which satisfy the final research requirements according to statistics.

\subsection{Sample Statistics}

The gender and regions of the collected samples are balanced distributed because of scientific and reasonable control for the respondents beforehand. Men are accounting for $50.1 \%$, for women, $49.9 \%$; the proportions of the seven cities are respectively 14\%; personal income mainly varies from 1001 - 5500 yuan; household monthly income varies from 2001 - 10,000 yuan; the proportion of primary school or below is $3.6 \%$, $6.4 \%$ for junior high level, $25.3 \%$ for senior high school, vocational school, technical secondary school, technical school level, $26.6 \%$ for college degree, $31.2 \%$ for bachelor degree, 5.8\% for double degree and master or above. See Table 2 for detailed sample information.

\section{Data Analysis and Discussion}

\subsection{Public Perception of CSR}

In the returned 1093 samples, we find that the proportion of the individuals who are willing to learn about CSR accounts for $34.9 \%$ of the total number, while $17.4 \%$ individuals who used to actively learn about CSR. This indicates that the concern degree and understanding of Chinese consumers are far from enough. The difference of willing to learn and used to learn suggests that the consumers initiative is not enough for learning CSR, quite a few consumers only have this thoughts but never put into practical action.

\section{Table 2. Sample statistics table.}

\begin{tabular}{|c|c|c|c|c|c|}
\hline Index & Attribute & Ratio & Index & Attribute & Ratio \\
\hline \multirow[t]{2}{*}{ Gender } & male & $50.10 \%$ & $\begin{array}{c}\text { Family } \\
\text { monthly income }\end{array}$ & 2000 and below & $9.10 \%$ \\
\hline & female & $49.90 \%$ & & 2001-7000 & $57.20 \%$ \\
\hline \multirow[t]{7}{*}{ Region } & Beijing & $15.10 \%$ & & $7001-10000$ & $13.30 \%$ \\
\hline & Shanghai & $14.40 \%$ & & $10001-20000$ & $13.80 \%$ \\
\hline & Guangzhou & $15 \%$ & & 20000 and above & $6.70 \%$ \\
\hline & Wuhan & $13.70 \%$ & Highest education & Primary school or below & $3.60 \%$ \\
\hline & Chengdu & $13.60 \%$ & & Junior high & $6.40 \%$ \\
\hline & Shenyang & $14.20 \%$ & & $\begin{array}{l}\text { Senior high school, vocational } \\
\text { school, technical secondary } \\
\text { school, technical school }\end{array}$ & $25.30 \%$ \\
\hline & Xi'an & $14 \%$ & & Junior college & $26.60 \%$ \\
\hline \multirow[t]{5}{*}{$\begin{array}{l}\text { Personal monthly } \\
\text { income }\end{array}$} & 1000 and below & $2.80 \%$ & & Bachelor degree & $31.20 \%$ \\
\hline & $1001-3500$ & $62 \%$ & & Double degree, master or above & $5.80 \%$ \\
\hline & $3501-5500$ & $18.20 \%$ & & & \\
\hline & $5501-10000$ & $9.80 \%$ & & & \\
\hline & Above 10000 & $7.20 \%$ & & & \\
\hline
\end{tabular}


The questionnaire is design as multiple-choice questions for the survey. Namely, what CSR aspects the enterprises need to achieve in the perspective of consumers. The result shows that top three aspects among those answers are as follows. 1. Active involvement in public welfare and donation (53.6\%); 2. Provide favorable welfare and working environment for the employees (39.7\%); 3. Reduce environment pollution and save resource as much as possible (24.3\%). The questionnaire also set a question, that is, what aspect of CSR shall be made the best after the above question? The top three answers were provision of favorable welfare and working environment (28\%), active involvement in public welfare and donation (24.2\%), product quality and after-sale service quality (15.2\%). In the first part of the investigation, the aspects of CSR included in the perspective of interviewees had different answers from that in the second part. This might be that, interviewees were not careful enough in providing answers because of multi-choice questions. In comparison, it is easy to find that active involvement in public welfare and donation/provision of favorable welfare and working environment acquired the higher concern, while the concern level of reducing environmental pollution, saving resource, product quality and after-sale quality is much lower than the above two aspects.

We adopted 5 points Likert when investigating the satisfaction degree of Chinese corporate social responsibility. 5 points represent very satisfied, 1 point represents very dissatisfied, and 3 points represent general impact. From the perspective of gender, the difference of male and female consumers is quite obvious $(p<0.01)$, the average value of male consumers is 2.58 , while for female consumers is 2.77 . The satisfaction degree of female consumers is higher than the male consumers. The female consumers believe Chinese enterprises perform well on CSR comparing with male consumers. The possible reason that may lead to this difference is that male consumers are more reasonable than female consumers, consider more when purchasing, and this rationality is not only from physiological difference but also from differently mastered information. It can be well explained in the survey that only 71 female consumers have actively learned CSR while for male consumers are 119. In general, under the same proportion of gender distribution, this indicates the male consumers have a more comprehensive understanding.

It is showed in the survey that the group difference is highly significant from the perspective of education level. In the 6 education levels of the survey, the average value of satisfaction degree of primary school or below is 2.85, 3.07 for junior high school level, 2.83 for senior high school, technical secondary school and vocational school level, 2.70 for college level, and 2.44 for double degree and master degree or above. We find that the education level is negatively correlated with the satisfaction degree $(p<0.01, \mathrm{a}=-0.152)$ by regression analysis. It can be concluded that the increase of education level will decrease the satisfaction degree of enterprise CSR performance. The reason might be that the increase of education level will enhance the concern degree of news and enable the consumers to have an overall understanding of current absence of CSR. Consequently, the consumers' satisfaction degree of company CSR performance decreases with the increase of education level.

This article investigates the satisfaction degree from the income situation of both personal income and household income. From the perspective of personal income, it is divided into 18 levels in the survey, thus to make detailed statistics of the personal income condition of the interviewees and conduct regression analysis on personal income and satisfaction degree. The result indicates that the satisfaction degree is negatively correlated with personal income $(p<0.01, \mathrm{a}=-0.134)$. From the perspective of household income, it is divided into 15 levels in the survey. Regression analysis is also conducted on the household income and satisfaction degree. The result suggests that the household income is negatively correlated with the satisfaction degree $(p<0.01$, a $=$ -0.116). In this way, there is a significant negative correlation between personal income/household income and CSR performance of the enterprises. The consumers with higher income acquire lower satisfaction degree. This might be that the relative increase of consumer income enables them to be more concerned with the social responsibility of enterprises except the basic question of food and clothing. In addition, the income increase enables the consumer to select more products and they may know more about the products which are produced by the company with non-performance of CSR, and this also may lead to the dissatisfaction when consumers are assessing a company's CSR performance.

\subsection{The Influence of Public Perception on the Product Selection}

This article also conducted influence degree of enterprise CSR performance on the consumer selection. 5 Likert is adopted as measuring standard in the research. 5 points represent huge impact, while 1 represents no impact.

From the perspective of gender difference, there is no obvious significant variation when male and female 
consumers selecting products. The impact average value for male consumers is 3.61 , the average value for female consumers is 3.67, significance test of group $P=0.396>0.05$. Significant positive correlation was found between highest education level $(p<0.01, \mathrm{a}=0.118)$ and family income $(p<0.05, \mathrm{a}=0.079)$ according to the respective regression analysis of impact degree, highest education level, personal income and household income. That is to say, the higher education degree leads to greater impact of CSR on consumer selection; in the same way, the higher household income leads to greater impact of CSR on consumer selection. See Table 3. We find no significant positive correlation between personal income and influence degree, and higher personal income does not change the influence degree obviously.

This article deeply studies the influence of CSR on consumers' selection from six aspects. The results are showed in Table 4, from which we could see that consumers show a relatively high recognition to enterprises with better CSR. The interviewees completely approve of choosing the products of enterprises with better CSR performance under the same price. The proportion of relative support and completely support is $96.4 \%$; and $77.5 \%$ respectively. Consumers still support the enterprises with better CSR performance even if their price is slightly higher.

This article also conducted regression analysis on the relationship between the above mentioned six questions and education background, personal income and household income, as showed in Table 5.

From the perspective of education background, the education background significantly correlated with the first question, and non-significantly correlated with other questions. The consumers with higher education background tend to choose the products of enterprises with better performance at the same price. Question 1 and question 2 in the above six questions aim to investigate the interviewees' acceptability of product price, therefore, this article concludes the two questions as CSR premium effect; while question 3 - 6 aim at investigating the acceptance degree of interviewees to relevant products, in this article, it is concluded as CSR quality effect. This article finds that the two categories can be divided for the six questions according to the factor analysis, and this agrees well with the above mentioned hypothesis (Table 6).

After adopting the factor analysis, this article conducted linear-regression analysis of CSR premium effect and CSR quality effect respectively on gender, education background and income situation. Regression results are showed in Table 7.

According to the above table, we find that the regression analysis on CSR premium effect and quality effect based on the factors of gender, education background and income, the result shows that only the highest education level is positively correlated with CSR premium effect, in other words, the consumers' acceptance of CSR premium effect increases with the increase of education level, namely, the consumers with higher education

Table 3. Statistical table of influence degree regression analysis.

\begin{tabular}{cccc} 
& Highest education & Personal income & Household income \\
\hline $\begin{array}{c}\text { What degree would CSR } \\
\text { affect your choice on } \\
\text { the products and services? }\end{array}$ & Sig. $=0.000$ & Sig. $=0.716$ & Sig. $=0.025$ \\
\hline
\end{tabular}

Table 4. Descriptive statistics of the influence of social responsibility on the consumers' product selection.

\begin{tabular}{|c|c|c|c|c|}
\hline & $\begin{array}{l}\text { Minimal } \\
\text { value }\end{array}$ & $\begin{array}{l}\text { Maximum } \\
\text { value }\end{array}$ & $\begin{array}{l}\text { Average } \\
\text { value }\end{array}$ & $\begin{array}{l}\text { Standard } \\
\text { deviation }\end{array}$ \\
\hline $\begin{array}{l}\text { 1. Give preference to the products or services } \\
\text { of the enterprise with better CSR performance under the same price }\end{array}$ & 1 & 5 & 4.46 & 0.644 \\
\hline $\begin{array}{l}\text { 2. Purchase the products or services at a slightly } \\
\text { higher price from the enterprises with better CSR performance }\end{array}$ & 1 & 5 & 3.78 & 1.050 \\
\hline $\begin{array}{l}\text { 3. Trust the new products or services of the } \\
\text { enterprises with better CSR performance }\end{array}$ & 1 & 5 & 4.11 & 0.802 \\
\hline $\begin{array}{l}\text { 4. Positively recommend the products or services } \\
\text { of the enterprise with better CSR performance }\end{array}$ & 1 & 5 & 4.09 & 0.916 \\
\hline $\begin{array}{l}\text { 5. Agree with the enterprises which perform well in CSR, } \\
\text { own higher products and services quality. }\end{array}$ & 1 & 5 & 4.18 & 0.822 \\
\hline 6. Trust the enterprises with better CSR performance more & 1 & 5 & 4.25 & 0.801 \\
\hline
\end{tabular}


Table 5. Regression analysis statistics for the influence of CSR on product selection.

\begin{tabular}{|c|c|c|c|c|c|c|}
\hline & $\begin{array}{l}\text { 1. Give preference to } \\
\text { the products or } \\
\text { services of the } \\
\text { enterprise with better } \\
\text { CSR performance } \\
\text { under the same price }\end{array}$ & $\begin{array}{l}\text { 2. Purchase the } \\
\text { products or services } \\
\text { at a slightly higher } \\
\text { price from the } \\
\text { enterprises with } \\
\text { better CSR }\end{array}$ & $\begin{array}{l}\text { 3. Trust the new } \\
\text { products or } \\
\text { services of the } \\
\text { enterprises with } \\
\text { better CSR } \\
\text { performance }\end{array}$ & $\begin{array}{l}\text { 4. Positively } \\
\text { recommend the } \\
\text { products or services } \\
\text { of the enterprises } \\
\text { with better CSR } \\
\text { performance }\end{array}$ & $\begin{array}{l}\text { 5. Agree with } \\
\text { the better CSR } \\
\text { enterprises } \\
\text { own higher } \\
\text { quality of products } \\
\text { and services. }\end{array}$ & $\begin{array}{l}\text { 6. Trust the } \\
\text { enterprises } \\
\text { with better } \\
\text { CSR } \\
\text { performance } \\
\text { more }\end{array}$ \\
\hline \multirow{2}{*}{$\begin{array}{l}\text { Education } \\
\text { Background }\end{array}$} & Sig. $=0.013$ & Sig. $=0.907$ & Sig. $=0.866$ & Sig. $=0.655$ & Sig. $=0.165$ & Sig. $=0.999$ \\
\hline & $\mathrm{a}=0.085$ & $\mathrm{a}=0.004$ & $\mathrm{a}=0.006$ & $\mathrm{a}=0.016$ & $a=-0.048$ & $\mathrm{a}=0.000$ \\
\hline \multirow{2}{*}{$\begin{array}{l}\text { Personal } \\
\text { Income }\end{array}$} & Sig. $=0.053$ & Sig. $=0.876$ & Sig. $=0.392$ & Sig. $=0.245$ & Sig. $=0.774$ & Sig. $=0.625$ \\
\hline & $a=0.079$ & $\mathrm{a}=0.006$ & $\mathrm{a}=0.035$ & $a=0.048$ & $a=-0.012$ & $\mathrm{a}=-0.020$ \\
\hline \multirow{2}{*}{$\begin{array}{l}\text { Household } \\
\text { Income }\end{array}$} & Sig. $=0.320$ & Sig. $=0.419$ & Sig. $=0.243$ & Sig. $=0.739$ & Sig. $=0.067$ & Sig. $=0.205$ \\
\hline & $\mathrm{a}=0.039$ & $\mathrm{a}=-0.032$ & $a=0.046$ & $\mathrm{a}=0.013$ & $\mathrm{a}=-0.072$ & $\mathrm{a}=-0.05$ \\
\hline
\end{tabular}

Table 6. Rotated components matrix of six questions.

Question
Components

1. CSR quality effects $\quad 2$. CSR premium effect

1. Give preference to the products or services of the

enterprise with better CSR performance under the same price

2. Purchase the products or services at a slightly

higher price from the enterprises with better CSR performance

3. Trust the new products or services of the

enterprises with better CSR performance

4. Positively recommend the products or services of better CSR enterprises

0.115

0.821

0.223

0.719

0.753

0.197

0.718

0.173

5. Agree with the better CSR enterprises own higher products and services quality.

0.787

0.066

6. Trust the enterprises with better CSR performance more

0.639

0.388

Note: adopt the Kaiser standardized varimax rotation.

Table 7. Regression analysis results.

\begin{tabular}{ccc}
\hline & CSR premium effect & CSR quality effects \\
\hline Gender & Sig. $=0.113$ & Sig. $=0.808$ \\
& $\mathrm{a}=-0.057$ & $\mathrm{a}=-0.009$ \\
Highest education & Sig. $=0.028$ & Sig. $=0.182$ \\
& $\mathrm{a}=0.078$ & $\mathrm{a}=-0.048$ \\
Personal income & Sig. $=0.257$ & Sig. $=0.656$ \\
& $\mathrm{a}=0.048$ & $\mathrm{a}=-0.019$ \\
Household income & Sig. $=0.853$ & Sig. $=0.292$ \\
& $\mathrm{a}=0.853$ & $\mathrm{a}=0.292$ \\
\hline
\end{tabular}

background owns higher premium tolerance. It might be because the increase of education level enables the consumers to be more rational during purchasing and product selection, and also, the proportion of price factor decreases gradually, in contrast, consumers lay more emphasis on the company CSR performance. However, in the analysis, we find that the four independent variables show no significant correlation with CSR quality effect. No distribution feature is presented in terms of demographics for the acceptance of CSR quality effect. It may be 
explained as the randomness of this type of consumers, who accept CSR quality effect as well as their individual preference and personality.

\section{Research Conclusion and Revelation}

\subsection{Research Conclusion}

Although Chinese economic level, residents' income level and education level are realizing leaping development, and consumer perception of CSR is still very limited. In the survey, it indicated that most of the consumers will not actively learn the CSR, not to mention even the few consumers who take the initiative to learn CSR. The possible reasons may be as follows: media propagating and leading, lacking of supervision strength; insufficient enterprise self-regulation, lacking of detailed information disclosure; shortage of public concern on CSR and lacking of supervision initiative.

At present, Chinese consumers are dissatisfied with the current enterprise undertaking of CSR, the situation varies obviously from the prospective of gender difference. The satisfaction degree of female consumers is higher than male consumers, and this difference may be as a result of the male consumers knowing more about CSR than when compares with female consumers (21.76\% of male consumers actively learned about CSR, while $12.98 \%$ for female consumers), so the performance of male consumers is more reasonable for more comprehensive referential information. Notable negative correlation between the satisfaction degree of enterprise undertaking of CSR and education background, family income and personal income are showed. Possible reasons may be as follows: the higher the education level of the consumers, the more attention will be paid on the knowledge accumulation and updating, which reflects on the more attention to the enterprise undertaking of CSR, so the available information of corporate social responsibility absence is more comprehensive and with deeper understanding. Besides, the increase of consumer's income enables them to think about other questions except food and clothing and then concerns their social rights. Meanwhile, the income increase also enables the consumers to select various products and get access to more products. The negative impact may swell and even worse if some enterprises fail to perform their CSR.

In addition, this article compares with other surveys of domestic scholars, and it's found that the public concern of CSR dimensions are changing with the social development. The different social development degree and different occurrences of social event may lead to the change of public concern of CSR dimensions, which is consistent with Carroll's viewpoint [7]. In the view of current stage, Chinese consumers lay more emphasis on the public welfare behavior and employ benefit of the enterprise, and the environmental protection and product safety are in the second place. It is interesting that though everyone complains about the bad CSR performance, but the environmental protection and product safety are not the most concerned issues, while the consumers give high expectations on public welfare and employee benefit. The possible reasons may be as follows. Firstly, the public is more concerned about the public welfare behavior because of frequent natural disasters; secondly, the public numbed by the continuously exposed product safety issues; furthermore, the public starts to pay more attention to personal economic benefit because commodity prices and wages are not synchronized.

From the perspective of gender, no different CSR influence is showed on the product selection of female consumers and male consumers. Although the concern degree and dissatisfaction degree of male consumers are higher than female consumers, in terms of product selection, there is no obvious difference. The possible reasons are listed in the followings. According to the results, CSR affects a lot when both female and male selecting products, some female consumers will consider the company CSR status as male consumers when selecting products, though the female consumers concern less about CSR and their satisfaction degree is slightly higher than the male consumers; from the perspective of education level, this influence varies a lot and shows significant positive correlation with education level, namely, the higher the education level is , the greater the impact on the products selection. This agrees well with the survey results of Webb and other scholars [25] [26]. It can be explained that the consumers with higher education level are more used to collecting information. The more information the consumers obtained, the broader channels they acquire the information and enable them to have better understanding of CSR and profound understanding of the negative influence of the enterprises with unqualified CSR performance; from the perspective of family, there is an obvious difference among this impact, the consumers with higher family income tend to be affected by CSR in a greater way when selecting product, which agrees with the survey results of Cui and other scholars [27]. The possible reasons may be that the consumers with higher income have a wide range of products selection, the subtle price difference among products 
may be ignored, and definitely, they will choose the products of the enterprises with better reputation.

The consumers hold a relatively high recognition degree toward the enterprises with better CSR performance. The social responsibility will affect the consumers' attitude toward the products to a great extent. Under the same price, 96.4\% consumers tend to choose the enterprises with better CSR performance, and $77.5 \%$ interviewees show their acceptance toward those enterprises even if their prices is slightly higher than other enterprises. In addition, the overflow effect of CSR is quite obvious. The consumers tend to trust more and highly evaluate the services and products of the enterprises which possess better CSR performance [11], and absolutely, this positive effect will affect other consumers.

\subsection{Relevant Revelation}

At present, Chinese public is far from a sufficient understanding of CSR and lacking the learning initiative. Although the understanding of CSR is still insufficient, the public is dissatisfied with current CSR performance of enterprises for the frequently exposed environmental pollution and product safety etc. The dissatisfaction increases with the increase of education background and income. The lacking of CSR will bring ruin upon the enterprises under the circumstance of Chinese continuous improvement of education degree.

A successful enterprise shall find an equilibrium point and focus on how to obtain the maximum satisfaction of the public toward its CSR performance by the minimum economic investment. The enterprise must lay emphasis on the performance of CSR, not only to acquire their own interest, but also pay more attention to the interest of the stakeholders. At the same time, enhance the report and propagation status of enterprise performance of CSR. The difference of demographics index of receivers must be of concerned during the propagating process, thus to obtain better reputation for the enterprise, and then to transfer this perception into maximum purchase rate, for instance, the enterprise shall establish positive corporate image by earning the trust of consumers, thus to increase the sales commissions. Consequently, in the propagating process of enterprise, the company shall put more emphasis on the consumers with higher education background for the correlativity between education level and CSR influential degree of consumer selection, in addition, this influence increases with the increase of education degree. In consequence, the sales performance will be maximally enhanced by the advocacy program which aims at the highly educated consumers.

The public most concerned CSR dimensions are variable according to the survey results of recent domestic researches. Different social background leads to different public attentions, and this also results in dynamic enterprise perception and CSR management. Based on the survey results of this article, the two most concerned dimensions of CSR respectively are contribution to public welfare programs and staff interest protection. The enterprise shall lay emphasis on the performance of the two dimensions and formulate optimized strategies to promote better and healthier corporate development.

Although this article obtains certain significant research results of CSR, there are still some limits. First of all, this article surveyed the public perception of CSR and the influence of this perception on the consumer consuming behavior, as well as discussed the differences of this influence on the demographics. The occupational factor was ignored when discussing the differences because of occupational diversity; second of all, this article made some researches from the perspective of consumers and neglected the perspective of other stakeholders; in the last, this article aimed at the large and medium-sized mainland cities, so the limitation may exist in terms of universality. Those limitations need to be noticed in the further researches.

\section{References}

[1] Chen, J.G. (2011) Chinese Corporate Social Responsibility Research Report 2011. Social Science Literature Press.

[2] Zhang, Z.G., Jin, X.C. and Li, G.Q. (2013) An Empirical Study on the Interactive and Intertemporal Influence between Corporate Social Responsibility and Corporate Financial Performance. Accounting Research, 8, 32-39.

[3] Ghoul, S., Guedhami, O. and Kwok, C.C.Y. (2011) Does Corporate Social Responsibility Affect the Cost of Capital? Journal of Banking and Finance, 35, 2388-2406. http://dx.doi.org/10.1016/j.jbankfin.2011.02.007

[4] Weng, Z.G., Liu, D.P. and Wang, P. (2013) How Consumer Attitudes of Charity and Sponsorship?-Based on the Dual-Attitude Theory. Journal of Marketing Science, 9,118-132.

[5] Davis, K. (1973) The Case for and against Business Assumption of Social Responsibilities. Academy of Management Journal, 16, 312-323. http://dx.doi.org/10.2307/255331

[6] Carroll, A.B. (1998) The Four Faces of Corporate Citizenship. Business and Society Review, 101, 1-7. 
http://dx.doi.org/10.1111/0045-3609.00008

[7] Carroll, AB. (1991) The Pyramid of Corporate Social Responsibility: Toward the Moral Management of Organizational Stakeholder. Business Horizons, 34, 39-48.

[8] Webster Jr., F.E. (1975) Determining the Characteristics of the Socially Conscious Consumer. Journal of Consumer Research, 2, 188-196. http://dx.doi.org/10.1086/208631

[9] Roberts, J.A. (1995) Profiling Levels of Socially Responsible Consumer Behavior: A Cluster Analytic Approach and Its Implications for Marketing. Journal of Marketing, 4, 97-116.

[10] Mohr, L.A., Webb, D.J. and Harris, K.E. (2011) Do Consumers Expect Companies to Be Socially Responsible? The Impact of Corporate Social Responsibility on Buying Behavior. Journal of Consumer Affairs, 35, 45-72. http://dx.doi.org/10.1111/j.1745-6606.2001.tb00102.x

[11] Sen, S. and Bhattacharya, C.B. (2001) Does Doing Good Always Lead to Doing Better? Consumer Reactions to Corporate Social Responsibility. Journal of Marketing Research, 38, 225-243. http://dx.doi.org/10.1509/jmkr.38.2.225.18838

[12] Mohr, L.A. and Webb, D.J. (2005) The Effects of Corporate Social Responsibility and Price on Consumer Responses. Journal of Consumer Affairs, 39, 121-147. http://dx.doi.org/10.1111/j.1745-6606.2005.00006.x

[13] Munilla, L.S. and Miles, M.P. (2004) The Corporate Social Responsibility Continuum as a Component of Stakeholder Theory. Business and Society Review, 110, 371-387.

[14] Xu, S.K. (2010) Conceptual Dimension, Perception and Practice of Chinese Corporate Social Responsibility. Reform of Economic System, 6, 60-65.

[15] George, S. and John, S. (2002) Enterprise, Government and Society. Huaxia Publishing House, Beijing.

[16] Chen, X. and Han, Y.Q. (2005) Hierarchical Model and Application of Enterprice Social Responsibility. China Industrial Economics, 9, 99-105.

[17] Digital 100 Market Consulting Co., Ltd. (2006) Public Evaluation Analysis Report of Corporate Social Responsibility.

[18] Jin, B. and Li, G. (2006) Preliminary Report of Corporate Social Responsibility Public Survey. Economic Management, 3, 110-112.

[19] Chen, J.G. (2009) Chinese Corporate Social Responsibility Research Report 2009. Social Science Academic Press, Beijing.

[20] Liu, F.J. and Li, H. (2014) A Research on the Internalization Mechanism of Consumers' Brand Attitude through Consumers' Enterprise Association Based on Corporate Social Responsibility-The Theory Construction and Empirical Test from Reciprocity and Identity Theory’s Perspective. China Soft Science, 3, 99-118.

[21] Fielding, M. (2007) Companies That Behave Responsibly Earn Good Rep, Consumers’ Attention. Marketing News, 41, 17-18.

[22] Zhang, Z.G., Liang, Z.G. and Yi, K.G. (2012) Research on Corporate Social Responsibility from the Stakeholder Perspective. China Soft Science, 2, 139-146.

[23] Barone, M.J., Miyazaki, A.D. and Taylor, K.A. (2000) The Influence of Cause Related Marketing on Consumer Choice: Dose One Good Turn Deserve Another? Journal of the Academy of Marketing, 28, 248-262. http://dx.doi.org/10.1177/0092070300282006

[24] Chang, Y.P., Yan, J. and Fang, Q. (2008) Effects of Enterprise’s Social Responsibility and Prices on Consumers’ Purchase Intention in China. Chinese Journal of Management, 5, 110-117.

[25] Webb, D.J. and Mohr, L.A. (1998) A Typology of Consumer Responses to Cause Related Marketing: From Skeptics to Socially. Journal of Public Policy Marketing, 2, 226-238.

[26] Servaes, H. and Tamayo, A. (2013) The Impact of Corporate Social Responsibility on Firm Value: The Role of Customer Awareness. Management Science, 59, 1045-1061. http://dx.doi.org/10.1287/mnsc.1120.1630

[27] Cui, Y., Trent, E.S. and Sullivan, P.M. (2003) Cause-Related Marketing: How Generation Y Responds. International Journal of Retail and Distribution Management, 31, 310-320. 